\title{
Corrigendum: Sliding Mode Tracking Control of a Wire-Driven Upper-Limb Rehabilitation Robot with Nonlinear Disturbance Observer
}

\author{
Jie Niu ${ }^{1 \dagger}$, Qianqian Yang ${ }^{1+}$, Xiaoyun Wang ${ }^{2}$ and Rong Song ${ }^{1 *}$ \\ ${ }^{1}$ Guangdong Provincial Engineering and Technology Center of Advanced and Portable Medical Devices, School of \\ Engineering, Sun Yat-sen University, Guangzhou, China, ${ }^{2}$ Injury Rehabilitation Hospital of Guangdong Province, Guangzhou, \\ China
}

Keywords: rehabilitation robot, wire-driven, upper limb, tracking control, sliding mode, nonlinear disturbance observer

\section{A corrigendum on}

\section{OPEN ACCESS}

Edited and reviewed by:

Jean-Claude Baron,

University of Cambridge,

United Kingdom

*Correspondence:

Rong Song

songrong@mail.sysu.edu.cn

${ }^{+}$Co-first authors

Specialty section This article was submitted to

Stroke,

a section of the journa

Frontiers in Neurology

Received: 09 April 2018

Accepted: 11 June 2018

Published: 28 June 2018

Citation:

Niu J, Yang $Q$, Wang $X$ and Song $P$ (2018) Corrigendum: Sliding Mode

Tracking Control of a Wire-Driven Upper-Limb Rehabilitation Robot with

Nonlinear Disturbance Observer.

Front. Neurol. 9:511.

doi: 10.3389/fneur.2018.00511
Sliding Mode Tracking Control of a Wire-Driven Upper-Limb Rehabilitation Robot with Nonlinear Disturbance Observer

by Niu, J., Yang, Q., Wang, X., and Song, R. (2017). Front. Neurol. 8:646. doi: 10.3389/fneur.2017.00646

In the original article, there was an error. The article partly overlaps with previously published conference proceedings. A correction has been made to add an Acknowledgments section.

\section{ACKNOWLEDGMENTS}

This article is partially based on our previous work which is shown in a conference paper (1).

The authors apologize for this error and state that this does not change the scientific conclusions of the article in any way.

\section{REFERENCES}

1. Niu J, Yang Q, Chen G, Song R. Nonlinear disturbance observer based sliding mode control of a cable-driven rehabilitation robot. IEEE Int Conf Rehabil Robot. (2017) 2017:664-9. doi: 10.1109/icorr.2017.8009324

Conflict of Interest Statement: The authors declare that the research was conducted in the absence of any commercial or financial relationships that could be construed as a potential conflict of interest.

Copyright (c) 2018 Niu, Yang, Wang and Song. This is an open-access article distributed under the terms of the Creative Commons Attribution License (CC BY). The use, distribution or reproduction in other forums is permitted, provided the original author(s) and the copyright owner(s) are credited and that the original publication in this journal is cited, in accordance with accepted academic practice. No use, distribution or reproduction is permitted which does not comply with these terms. 